УДК 78.07

DOI https://doi.org/10.31723/2524-0447-2020-30-2-7

Леся Богданівна Романюк

ORCID: 0000-0003-0206-7420

кандидат мистецтвознавства,

доцент кафедри музичної україністики

та народно-інструментального мистецтва

Прикарпатського національного університету імені Василя Стефаника leromanyk@ukr.net

\title{
ФОРТЕПІАННА ТВОРЧІСТЬ КОМПОЗИТОРІВ ЗАКАРПАТТЯ ЯК ВІДДЗЕРКАЛЕННЯ БАГАТОНАЦІОНАЛЬНОГО КУЛЬТУРНО-МИСТЕЦЬКОГО ПРОСТОРУ РЕГІОНУ
}

Мета роботи полягає у висвітленні фортепіанної творчості закарпатських композиторів через призму поліетнічності культурно-мистецького середовища регіону. Методологія дослідження опирається на комплекс методів дослідження: метод теоретичного аналізу наукової літератури з питань регіональної музичної культури; компаративний метод, який дозволив зробити порівняльну характеристику етапів розвитку музичного життя Закарпаття в цілому та фортепіанного мистецтва зокрема; аналітичний - для дослідження концептуальних підходів щодо трактування мистецького явища фортепіанної творчості; метод узагальнення, який дав можливість об'єднати та згрупувати досліджені матеріали за єдиною характерною ознакою. Наукова новизна полягає в тому, що фортепіанна творчість композиторів Закарпаття розглядається в контексті поліетнічності регіону; проведена пошукова робота та введено у науковий обіг матеріали, пов'язані із фортепіанною музикою сучасних закарпатських композиторів, серед яких Р. Меденцій, В. Цанько. Висновки. Фортепіанна творчість композиторів Закарпаття є самобутнім і динамічним явищем, яке не тільки охоплюе відомі жанрово-стилістичні пласти, але й виявляє тенденції до самооновлення, стильового і видового збагачення. За всієї різноманітності, у процесі аналізу провідних тенденцій та фортепіанних композицій, виразно прослідковуються стійкі риси, що у сукупності відбивають стилістичні закономірності. Вони властиві як місцевій, регіональній, так і загалом українській музичній культурі, вагоме місце y якій посідає творчість закарпатських композиторів. У контексті сказаного їх поєднує: стильова багатозначність авторського висловлювання; розмаїття жеанрів і форм, серед яких одне з провідних місиь належить камерно-інструментальній фортепіанній музиці; тяжіння

(C) Романюк Л. Б., 2020 
як до ииклічних форм і розгорнутих композицій (фантазія, варіації, сюїта, кониерт, соната), так і до мініатюр; поєднання яскравих пісенно-мелодичних ліній з подекуди симфонізованим, складним супроводом; досконале володіння як традиційними, так і сучасними технічними прийомами письма на багатонаціональній фольклорній (украӥнській, угорській та чеській) основі.

Ключові слова: фортепіанна творчість, композитори Закарпаття, культурно-мистецький простір, поліетнічність.

Romaniuk Lesia Bohdanivna, Candidate of Art Criticism (Ph.D.), Associate Professor at the Department of Music Ukrainian Studies and Folk Instrumental Art of Vasyl Stefanyk Precarpathian National University

Piano creativity of composers of Transcarpathia as a reflection of the multinational cultural and artistic space of the region

Research objective. The aim of the work is to highlight the piano work of Transcarpathian composers through the prism of polyethnic cultural and artistic environment of the region. The methodology of the research is based on a set of research methods: the method of theoretical analysis of the scientific literature on regional music culture; comparative method, which allowed to make a comparative description of the stages of development of musical life in Transcarpathia in general and piano art in particular; analytical method helped to study conceptual approaches to the interpretation of the artistic phenomenon of piano creativity; generalization method, which made it possible to combine and group the studied materials on a single characteristic. The scientific novelty is that the piano works of Transcarpathian composers are considered in the context of polyethnicity of the region; the research work was carried out and materials related to the piano music of contemporary Transcarpathian composers, including $R$. Medentsy and $V$. Tsanko, were put into scientific circulation. Conclusions. Piano works of Transcarpathian composers are an original and dynamic phenomenon, which not only covers the well-known genre and stylistic layers, but also shows clear tendencies to self-renewal, stylistic and species enrichment. For all the variety, in the process of analysis of trends and piano compositions, there are clearly stable features that together reflect the stylistic patterns. They characterize both local, regional and Ukrainian music culture in general, in which the work of Transcarpathian composers occupies an important place. In the context of what has been said, they are united by stylistic ambiguity of the author's statement; a variety of genres and forms, among which one of the leading places belongs to chamber and instrumental piano music; attraction to cyclic forms and detailed compositions (fantasy, variations, suite, concert, sonata), as well as to miniatures; a combination of bright song and melodic lines with sometimes symphonic, complex accompaniment; perfect mastery of both traditional and modern techniques of writing on a multinational folklore Ukrainian, Hungarian and Czech basis.

Key words: piano creativity, Transcarpathian composers, cultural and artistic space, polyethnicity. 
Романюк Леся Богдановна, кандидат искусствоведения, доцент кафедры музыкальной украинистики и народно-инструментального искусства Прикарпатского национального университета имени Василия Стефаника

Фортепианное творчество композиторов Закарпатья как отражение многонационального культурно-художественного пространства региона

Цель работы заключается в освещении фортепианного творчества закарпатских композиторов через призму полиэтничности культурно-художественной среды региона. Методология исследования базируется на комплексе методов исследования: метод теоретического анализа научной литературы по вопросам региональной музыкальной культуры; компаративный метод, который позволил сделать сравнительную характеристику этапов развития музыкальной жизни Закарпатья в иелом и фортепианного искусства в частности; аналитический - для исследования концептуальных подходов к трактовке художественного явления фортепианного творчества; метод обобщения, который дал возможность объединить и сгруппировать изучаемые материалы по общим характерным признакам. Научная новизна заключается в том, что фортепианная творчество композиторов Закарпатья рассматривается в контексте полиэтничности региона; проведена поисковая работа и введены в научный оборот материалы, связанные с фортепианной музыкой современных закарпатских композиторов, среди которых Г. Меденций, В. Цанько. Выводы. Фортепианное творчество композиторов Закарпатья является самобытным и динамичным явлением, которое не только охватывает известные жсанрово-стилистические пласты, но и проявляет тенденции к самообновлению, стилевому и видовому обогащению. При всем разнообразии в процессе анализа господствующих тенденций и фортепианных композиций определенно прослеживаются устойчивые черты, которые в совокупности отражают стилистические закономерности. Они свойственны как местной, региональной, так и в иелом украинской музыкальной культуре, важное место в которой занимает творчество закарпатских композиторов. В контексте сказанного их объединяет: стилевая многозначность авторского высказывания; разнообразие жканров и форм, среди которых одно из ведущих мест принадлежит камерно-инструментальной фортепианной музыке; склонность как к ииклическим формам и крупным композициям (фантазия, вариации, сюита, концерт, соната), так и к миниатюрам; сочетание ярких песенно-мелодических линий с симфонизированным, сложным сопровождением; владение как традиционными, так и современными техническими приемами письма на многонациональной фольклорной (украинской, венгерской и чешской) основе.

Ключевые слова: фортепианное творчество, композиторы Закарпатья, культурно-художественное пространство, полиэтничность.

Актуальність теми дослідження. Важливим завданням сучасного українського мистецтвознавства є вивчення та популя- 
ризація культурно-мистецьких традицій різних регіонів України, а також з'ясування взаємозв'язків між ними. Протягом тривалого часу основну увагу дослідників, насамперед, привертають художні досягнення представників Київської, Харківської, Одеської та Львівської шкіл, тоді як культура інших, віддалених від столиці або менших регіонів, залишається мало дослідженою. Однак без грунтовного вивчення мистецької палітри цих регіонів важко науково точно і об'єктивно відобразити багатоманітний культурно-мистецький процес у нашій державі. Серед таких недостатньо досліджених $€$ культура Закарпаття, яке здавна вважається одним із найбільш самобутніх в контексті розвитку мистецьких традицій. Музичне мистецтво Закарпаття сформувалося у поєднанні різнонаціональних культур: української, угорської, румунської, словацької, що зумовлено територіальною близькістю. Тому взаємопроникнення їх фольклорних елементів визначає специфіку як закарпатської народної музики, так і є невід’ємною рисою професійної композиторської практики.

Вихідцями із Закарпаття є ціла плеяда видатних композиторів та виконавців, серед яких Костянтин Матезонський (1794-1858), Емілій Талапкович (1834-1889), Іоан Бокшай (1874-1940), Дезидерій Задор (1912-1985), Петро Милославський (1896-1954), Михайло Кречко (1925-1996), Іштван Мартон (1923-1996), Свген Станкович (1943), Гізелла Ципола (1943), Василь Гайдук (1938), Володимир Волонтир (1956), Віктор Теличко (1957), Віктор Янцо (1978), Роман Меденцій (1981). На жаль, творчість багатьох з названих довгий час не розглядалась у загальнонаціональному контексті розвитку українського мистецтва, а діяльність композиторів більш сучасного покоління, серед яких Віктор Теличко, Володимир Волонтир, Роман Меденцій, Василь Цанько, тільки частково стала об'єктом спеціальних досліджень у наукових музикознавчих працях в контексті розгляду їх фортепіанного доробку.

У працях Я. Рак та Н. Піцур представлено в загальному життєвий і творчий шлях Дезидерія Задора та Іштвана Мартона. Л. Микуланинець у дисертаційному дослідженні вивчає етнокультурні аспекти становлення професійної музичної культури Закарпаття другої половини XX століття. Музичне мистецтво Закарпаття у його професійних вимірах розглядається у музикознавчих збірках статей під редакцією В. Теличка та 
Л. Мокану. Однак праць, які б стосувалися вивчення інструментальної музики Закарпаття, зокрема, фортепіанної, на жаль, досі мало. А в контексті поліетнічного синтезу фортепіанна творчість закарпатських композиторів належним чином ще не вивчалась. Саме це зумовило актуальність вибору теми наукового дослідження.

Метою дослідження $є$ висвітлення фортепіанної творчості закарпатських композиторів через призму поліетнічності культурно-мистецького середовища регіону.

Наукова новизна виявляється в тому, що було проаналізовано фортепіанну творчість композиторів Закарпаття в контексті поліетнічності регіону; проведена пошукова робота та вперше введено у науковий обіг матеріали, пов'язані із фортепіанною музикою сучасних закарпатських композиторів, серед яких Роман Меденцій, Василь Цанько.

Виклад основного матеріалу. Музична культура Закарпаття розвивалася під впливом складних історико-політичних обставин і тому є однією з наймолодших в Україні. Це зумовлено тим, що Закарпаття до другої половини XX століття було у складі різних держав (Угорщини, Трансільванії, Австро-Угорщини, Чехословаччини), і лише після Другої світової війни було приєднане до України. Саме ці обставини значно уповільнили розвиток культуротворчих процесів. В основному це було пов'язано із відсутністю місцевих спеціалізованих навчальних закладів (вищу освіту музиканти Закарпаття здобували у Празькій і Будапештській консерваторіях), а також бібліотек, великих концертних залів тощо, але разом з тим мало вирішальне значення для становлення iii самобутності.

На музичну культуру Закарпаття значний вплив мали австро-угорські музичні традиції, адже до 1919 року воно входило до Австро-Угорщини, а з 1939 до 1944 року - Угорської імперії. Влада проводила політику мадяризації та нав'язувала свою культуру, що мало як позитивні, так і негативні наслідки. Значна активізація музичного життя, яка вплинула на розвиток професійного музичного мистецтва Закарпаття, спостерігається у 20-30-х роках XX століття. Загалом, це було зумовлено віднесенням регіону до складу Чехословаччини у період 1919-1939 рр. та впливом «празької школи», яка дала цілу плеяду високофахових музикантів, що своєю діяльністю спричинилися до розвитку культури [7]. 
Концертне життя Закарпаття у першій половині XX століття було насичене виступами місцевих музикантів Д. Задора, Ж. Лендєла, Я. Гергелі, В. Ромішовської, які отримали високу європейську освіту. Через пожвавлення концертного життя музична культура краю збагачується творчими принципами різних виконавських і композиторських шкіл та провідними тенденціями європейського музичного мистецтва, складається 3 елементів різноетнічних культур, творчого доробку представників різнонаціональних груп [2].

В історії української музики Закарпаття представлено цілою низкою відомих композиторів, які виявили яскравість та індивідуальність обдарування у різних жанрах та виконавських сферах, серед яких особливе місце належить фортепіанній творчості. Серед них: Дезидерій Задор, Іштван Мартон, Евген Станкович, Василь Гайдук, Володимир Волонтир, Віктор Теличко та інші. Фортепіанна музики композиторів цього регіону синтезувала різноетнічний фольклор та загальноєвропейські традиції. Вплив європейського модернізму у першій третині минулого століття, жорсткі обмеження реалізму у другій його третині були подолані появою так званого «українського авангарду» у шістдесяті роки XX століття, їх вплив відчутний у фортепіанній творчості закарпатських композиторів Дезидерія Задора та Іштвана Мартона. Виникнення широкого спектра різноманітних напрямів зумовило процес стильового оновлення їх творчості, сприяло експериментаторству у сфері композиторської техніки [1].

Серед видатних представників музичного Закарпаття особливе місце належить Дезидерію Свгеновичу Задору - композитору, піаністу, педагогу, хоровому диригенту, науковцю-теоретику, збирачу народного фольклору, який вважається одним із фундаторів професійної композиторської та виконавської школи регіону, в тому числі й у сфері фортепіанної музики. Велику роль у формуванні індивідуального стилю композитора відіграла музична атмосфера Праги, де він навчався та його угорське походження, що відбилося на сприйнятті та переосмисленні ним у творчості національного фольклору. Через композиторську діяльність музикант зумів поєднати найкращі професійні європейські композиторські традиції із закарпатськими фольклорними інтонаціями. Крім угорської, музикант добре знав українську народну творчість. Фольклор- 
ний тематизм у Д. Задора поєднується із певними стильовими ознаками неокласицизму та романтизму, що відображено у його фортепіанних творах, серед яких: Закарпатська сюїта для фортепіано 3 оркестром, Етюд e-moll, Соната h-moll, Концерт для фортепіано з оркестром, «Скерцо», «Гопак», фуга, варіаціі на українську тему «Перелаз» для 2-х фортепіано у 8 рук. У результаті аналізу цих композицій зроблено висновок, що автору притаманний природний синтез народнопісенних інтонацій із новими для свого часу естетико-стильовими напрямами європейського мистецтва, перенесення їх на національний грунт, засвоєння досвіду європейської та української музичних шкіл [6].

Найближчим послідовником та учнем Дезидерія Задора був Іштван Мартон, який також вважається одним із основоположників професійної композиторської школи Закарпаття. Мистецька спадщина I. Мартона включає біля 400 творів у різних жанрах, де органічно поєднались елементи різних національних культур: української, угорської, словацької, що вирізняє його з поміж інших композиторів регіону. У своїй фортепіанній творчості I. Матрон продовжував стильовий напрям пізнього романтизму, який розширив за рахунок надання музичній інтонацї експресивності, що $\epsilon$ типовим для музики XX століття, та відображав тенденції української «нової фольклорної хвилі» [5.]. У його творчості важливе місце займають жанри камерно-інструментальної музики, звернення до яких зумовлено впливом композиторських пошуків 1960-80-х років та представлено фортепіанними творами «Пісня», «Колискова і Скерцо» для скрипки і фортепіано, «Новелета», «Спомин», «Елегія», «Експромт», «Вальс» для фортепіано в 4 руки тощо. У всіх цих творах композитора відчувається національний колорит. Глибоке знання карпатського фольклору, гармонійне відчуття єдності різних національних традицій були властиві його індивідуальному стилю. Мелодика творів композитора та іiі фольклорні джерела тісно пов'язані з пісенною закарпатською інтонацією. Звідси і специфічна загострена ритміка, що походить від угорських мовних зворотів і є особливістю закарпатського фольклору. Імпровізаційний спосіб музичного викладу, близький до манери виконання угорських циган, запозичує композитор від народного музикування, у стилізованому звучанні відтворює виконавські традиції троїстих музик. У своїй творчості 
I. Мартон вміло поєднує буквальне цитування народного фольклору із його переосмисленням.

Закарпатські композитори сучасного покоління, що творять у жанрах фортепіанної музики продовжують традиції, закладені попередниками. Яскравою індивідуальністю вирізняються: Віктор Теличко, Володимир Волонтир, Роман Меденцій, Василь Цанько. Притаманні різнонаціональному колориту відкритість до світу та розуміння його розмаїття, діалогічність у стосунках із природним і людським довкіллям, мрійливість та іноді дух гіперболізації стали основними рисами фортепіанної музики композиторів Закарпаття другої половини XX - початку XXI ст. Митці переосмислюють стилістику попередніх епох на національному грунті, поєднуючи ï із яскраво індивідуальними елементами у оригінальній взаємодії. Водночас спостерігається синтез поліетнічних (українських, угорських, румунських, словацьких тощо) фольклорних елементів із надбаннями східноєвропейських та західноєвропейських музичних культур [3, с. 184-188]. Музична мова, що грунтується на переосмисленні різнонаціонального фольклору поєднується із сучасною, застосовуються прийоми різних композиторських технік, серед яких сонористика, алеаторика, додекафонія, залучають джазові гармонії, рокові ритми. Ці прийоми використовують як новітній спосіб передачі ідейно-образного змісту, а не як самоціль. У фортепіанній сфері вирізняються композиції, написані як для соло інструмента, так і для ансамблю, як для майстерних виконавців, так і для дітей. Вражаючим також є жанрове розмаїття творчості.

Багатогранною, яскравою, насиченою фольклорними інтонаціями є фортепіанна творчість Віктора Теличка. Різноманітність його виразових засобів, вміння майстерно ними користуватися свідчать про добру обізнаність 3 можливостями інструмента. Фортепіанна музика В. Теличка є вагомою частиною його творчого доробку: Варіації, Соната, цикл прелюдій, дві сюїти для 2-х фортепіано, «Карпатське капричіо» для 2-х (3-х) фортепіано з оркестром, «Дитячий альбом», ансамблі в 4 руки, транскрипція «Фарандоли» для 2-х фортепіано у 8 рук, транскрипція «Рондо» Б. Сметани для 3-х фортепіано в 12 рук [4, с. 168-178].

Основні напрямки творчості сучасника В. Теличка Володимира Волонтира як композитора безпосередньо пов'язані $з$ його виконавською діяльністю. Найважливіша ділянка (хорова 
музика) найширше представлена у концертній практиці, адже В. Волонтир є керівником Мукачівського зразкового Хору хлопчиків та юнаків. Окремий жанровий різновид творчості композитора складають його фортепіанні твори малої форми (прелюдії, джазові експромти, п’єси «Спогад», «Весна», твори для дітей), та більш масштабні за змістом і формою композиції (Варіації, поема «Пам’ять», цикл «Роздуми»).

Серед багатожанрової творчості композитора молодшого покоління Романа Меденція особливо цікавою і оригінальною є фортепіанна музика, якою композитор почав займатись з раннього дитинства, мріючи обрати фах піаніста-виконавця. Саме цей факт послужив відправною точкою у процесі написання перших композицій автора. Велике значення для формування індивідуального композиторського стилю митця мала творчість Ф. Шопена, Ф. Ліста, С. Рахманінова. Твори для фортепіано, невеликі мініатюри, композитор почав писати ще в юнацькі роки. Перший масштабний твір «Романтична фантазія» для фортепіано з'явився в 2001 році, в ньому відчувається вплив романтичної епохи, музики С. Рахманінова і Ф. Ліста. Наступним твором у музичному доробку автора стала фортепіанна сюїта, присвячена Ф. Шопену, що написана в 2002 році. Сюїта складається з 4 частин: прелюдія, вальс, полонез, ноктюрн; технічно твір складний для виконання, близький до стилю Ф. Шопена.

Новим етапом творчості Р. Меденція можна вважати фортепіанну сонату, написану для фестивалю «Сучасна музика молодих композиторів» і присвячену Джону Кейджу - відомому американському композитору XX століття. Сама назва твору C-A-G-E є абревіатурою прізвища Кейдж, а ці 4 звуки (своєрідна криптограма) відіграють в сонаті ключову роль, оскільки на них побудовано увесь твір. Соната є складним для виконання віртуозним твором, насиченим сучасними прийомами композиторської техніки. Ще одним твором-присвятою видатному композитору і піаністу Д. Задору є Концерт-фантазія Р. Меденція «Карпати». У ньому відчутна яскрава колористика гір, завдяки різнобарвному тембру традиційного народного інструменту цимбали, та інтонаційній близькості до народного закарпатського фольклору, що поєднується 3 мелодійністю звучання академічного фортепіано. Загалом творчість композитора відображає загальні тенденцї розвитку українського та європейського музичного мистецтва, для 
якого характерна різноманітна постмодерна стилістика, програмний синтез, певна театралізація інструментальних творів, своєрідна національна декоративність і виразність. У своїх творах він послуговується сучасними композиторськими техніками, застосовує незвичні прийоми гри на роялі. Водночас виразно проявляються також нефольклорні принципи і традиції європейського авангарду ХХ століття.

Творчість молодих сучасних композиторів складає майбутнє української музичної культури. Вони сповнені бажанням відкривати нові сторінки вітчизняної музики, експериментувати, відображати сучасне життя, власний світ відчуттів та переживань. До цієї когорти молодих митців належить Василь Цанько, у творчості якого переважають фортепіанні твори різних жанрових різновидів, серед яких: Сюїта на одну тему: Прелюдія, Фуга і Вальс, Карпатський Ескіз, Маскарад, Хорал, Соната та три ескізи. «Сюїта на одну тему» В. Цанька $\epsilon$ даниною епосі Бароко, віртуозним і яскравим твором, який перейнятий єдиним настроєм. В основі ідейно-образного змісту - розкриття глибокого внутрішнього світу людини, іiі пошуки змісту життя. Натомість «Карпатський ескіз» сповнений колоритом самобутнього закарпатського краю, що виявляється у характерному мелодизмі, інтонаційних зворотах та гармонічному різнобарв'ї. Незважаючи на те, що молодий композитор ще знаходиться у процесі пошуку індивідуального стильового обличчя, вже тепер у його творчості поєднано риси експресіонізму та імпресіоністичний колоризм.

Висновки. Отже, у процесі дослідження було розглянуто фортепіанну творчість композиторів різних поколінь: Д. Задора, І. Мартона, В. Волонтира, В. Теличка, Р. Меденція, В. Цанька у всій іiі різноплановості. Визначено їх пріоритети у контексті музичної культури Закарпаття і України в цілому. Різні за індивідуальним стилем композитори об'єднані єдиним прагненням писати яскраво національну музику, у повній мірі оновлену сучасними музично-технічними прийомами. Незважаючи на суттєві відмінності у філософських, естетичних та стильових засадах творчості, вони виявляють спільність у ставленні до глибинних фольклорних джерел, увазі до національно і регіонально характерних ознак, що дозволяє твердити навіть про наявність закарпатської композиторської школи. Важливими рисами їх творчості є: стильова різноманітність авторського висловлювання; розмаїття жанрів 
і форм, серед яких одне з провідних місць належить камерно-інструментальній фортепіанній музиці як для виконавців-професіоналів, так і для дітей; тяжіння як до циклічних форм і розгорнутих композицій по типу фантазії, варіацій, сюїти, концерту, сонати, так і до мініатюрних композицій; поєднання яскравих пісенно-мелодичних ліній 3 подекуди симфонізованим, складним супроводом; досконале володіння як традиційними, так і сучасними технічними прийомами письма і водночас багатонаціональна фольклорна інтонаційно-тематична основа, яка поєднала українську, угорську та чеську традиції.

Відтак фортепіанна музика композиторів Закарпаття $\epsilon$ яскравим, самобутнім і динамічним явищем, яке не тільки охоплює відомі жанрово-стилістичні пласти, але й виявляє виразні тенденції до самооновлення, стильового і видового збагачення. За всієї різноманітності у процесі аналізу тенденцій та музичних фортепіанних композицій виразно прослідковуються стійкі риси, що в сукупності відбивають стилістичні закономірності. Вони властиві як місцевій, регіональній, так і загалом українській музичній культурі, вагоме місце у якій посідає творчість закарпатських композиторів.

\section{СПИСОК ЛІТЕРАТУРИ}

1. Бідзіля В. Історія культури Закарпаття на рубежі нашої ери. Київ : Наукова думка, 1971, 207 с.

2. Грін О. Професійне музичне мистецтво Закарпаття XIX - першої половини XX століття: історичний аспект. Ужгород : Госпрозрахунковий редакційно-видавничий відділ управління у справах преси та інформації, 2004. 160 с.

3. Микуланинець Л.М. Етнокультурологічне становлення професійної музичної культури Закарпаття у другій половині $X X$ століття. Мистецтвознавчі записки: зб. наук. праць. Вип. 15. Київ : Міленіум, 2009. С. 184-188.

4. Оленич К. Композитор Віктор Теличко. Професійна музична культура Закарпаття: етапи становлення. Вип. 1. Ужгород, 2005. C. $168-178$.

5. Піцур Н. Іштван Мартон. Творчий портрет. Ужгород : Госпрозрахунковий редакційно-видавничий відділ комітету інформації, 1998. 64 c.

6. Рак Я. Творчий портрет Дезидерія Євгеновича Задора : монографічний нарис. Ужгород : Закарпаття, 1997. 36 с.

7. Росул Т. I Музичне життя Закарпаття 20-30-х років XX століття : монографія. Ужгород : Полі Прінт, 2002. 208 с. 


\section{REFERENCES}

1. Bidzilya, V. (1971). Istoriia kultury Zakarpattia na rubezhi nashoi ery [History of Transcarpathian culture at the turn of our era]. Kyiv : Naukova Dumka.

2. Green, O. (2004). Profesiine muzychne mystetstvo Zakarpattia XIX pershoi polovyny XX stolittia: istorychnyi aspect [Professional musical art of Transcarpathia in the $19^{\text {th }}$ - first half of the 20h century : historical aspect]. Uzhhorod : Self-supporting editorial and publishing department of the press and information department.

3. Mykulanynets, L. (2009). Etnokulturolohichne stanovlennia profesiinoi muzychnoi kultury Zakarpattia u druhii polovyni XX stolittia [Ethnocultural formation of professional musical culture of Transcarpathia in the second half of the $20^{h}$ century]. Art notes : collection. Science. wash. Vip. 15. K. : Millennium.

4. Olenych, K. (2005). Kompozytor Viktor Telychko. Profesiina muzychna kultura Zakarpattia: etapy stanovlennia [Composer Victor Telichko. Professional musical culture of Transcarpathia : stages of formation]. Issue 1. Uzhhorod.

5. Pitsur, N. (1998). Ishtvan Marton. Tvorchyi portret [Istvan Marton. Creative portrait]. Uzhhorod: Self-supporting editorial and publishing department of the information committee.

6. Rak, J. (1997). Tvorchyi portret Dezyderiia Yevhenovycha Zadora : monohrafichnyi narys [Creative portrait of Desidery Evgenyevich Zador : monographic essay]. Uzhhorod : Zakarpattia.

7. Rosul, T. (2002). Muzychne zhyttia Zakarpattia 20-30-kh rokiv $X X$ stolittia [Musical life of Transcarpathia in the 20-30s of the 20th century] : monograph. Uzhhorod : Poly Print. 